\title{
Observations on glucose tolerance and plasma levels of free fatty acids and insulin in the zinc-deficient rat
}

\author{
By J. QUARTERMAN and E. FLORENCE* \\ Rowett Research Institute, Bucksburn, Aberdeen $A B_{2}{ }_{9} S B$ \\ (Received 12 fuly 197 I - Accepted 6 December 1971)
}

\footnotetext{
I. The glucose tolerance and plasma free fatty acid and insulin concentrations were compared in zinc-deficient rats and rats given a $\mathrm{Zn}$ supplement.

2. The glucose tolerance of $\mathrm{Zn}$-deficient rats was not different from that of rats given a $\mathrm{Zn}$ supplemented diet.

3. The plasma insulin concentration after a dose of glucose tended to be lower in $\mathrm{Zn}$ deficient rats than in those given a $\mathrm{Zn}$ supplement.

4. During the development of $\mathrm{Zn}$ deficiency there was a transient rise in plasma free fatty acid concentration.
}

Zinc is closely associated with insulin in the characteristic dark-staining granules of the $\beta$-cells of the islets of Langerhans (Logothetopoulos, Kanek, Wrenshall \& Best, I964; Petkov \& Galabova, 1969) and it was considered possible that changes in the Zn status of an animal could affect the production, storage or release of insulin, especially since the rat pancreas as a whole suffers a greater decrease in $\mathrm{Zn}$ content than most tissues when the animals become Zn-deficient (Williams \& Mills, 1970).

In the $\mathrm{Zn}$-deficient animal, changes have been observed in adipose-tissue metabolism (Quarterman, Mills \& Humphries, I966; Quarterman, 1969) and in carbohydrate metabolism (Quarterman et al. I966; Hove, Elvehjem \& Hart, I937). These changes, however, are the sort which could be affected by differences in feeding pattern between an experimental, e.g. Zn-deficient, animal with a reduced food intake and a pair-fed control receiving a diet supplemented with $\mathrm{Zn}$. The deficient animal will have a fairly constant rate of food intake in any one day, but the control animal, receiving a quantity of food much less than its appetite requires, will adopt a mealeating pattern of feeding. Some effects of feeding pattern and previous day's food intake on glucose tolerance and plasma free fatty acid (FFA) concentration and plasma insulin levels have been described in the preceding paper (Florence \& Quarterman, 1972). In the present paper the observations of changes in carbohydrate and lipid metabolism in $\mathrm{Zn}$ deficiency are re-examined and extended, taking into account the possible effects of differences in feeding pattern.

\section{EXPERIMENT AL}

Most procedures used in this work, including the measurement of glucose tolerance and the imposition of feeding patterns on the experimental rats, are described by Florence \& Quarterman (1972).

* Present address: National Institute for Research in Dairying, Shinfield, Reading RGz 9AT. 


\section{$Z n$-deficient diets and animals}

Hooded Lister rats (Rowett strain), maintained under minimal disease conditions, were used in all the experiments. Diets low in $\mathrm{Zn}$ were prepared as described by Williams \& Mills ( 1970 ), and were used when they contained less than I $\mu \mathrm{g} / \mathrm{g} \mathrm{Zn} ; 40$ $\mu \mathrm{g} / \mathrm{g} \mathrm{Zn}$ as $\mathrm{Zn} \mathrm{SO} \mathrm{S}_{4}$ was added to the $\mathrm{Zn}$-supplemented diets. Rats given the low-Zn diet lost appetite, ate continuously for $24 \mathrm{~h} / \mathrm{d}$ and ceased to grow after 3 or $4 \mathrm{~d}$. Thereafter they ate about $5.5 \mathrm{~g}$ food a day (Williams \& Mills, I970). Control rats were individually pair-fed with $\mathrm{Zn}$-deficient rats and either meal-fed from a pot or continuously fed by means of a rotary feeder supplying food continuously throughout $24 \mathrm{~h}$ (Quarterman, Williams \& Humphries, 1970).

\section{Glucose-tolerance tests}

The glucose tolerance of ten $\mathrm{Zn}$-deficient rats, 30-50 d of age, was compared with that of ten pair-fed, continuously fed rats of the same age given the $\mathrm{Zn}$-supplemented diet. The tolerance of each rat on the $\mathrm{Zn}$-supplemented diet was measured a day after its $\mathrm{Zn}$-deficient pair-mate so that the two animals were comparable with regard both to feeding-pattern and to the preceding day's food intake.

\section{Analytical methods}

$\mathrm{Zn}$ determinations were made by atomic absorption spectrophotometry on wetashed samples.

Ketone bodies in plasma were estimated by the method of Tanayama \& Ui (I963) and cholesterol by a colorimetric method using dimethylbenzene sulphonic acid (Biochemica Test Combination, C. F. Boehringer \& Sons Itt, Mannheim, Germany).

\section{RESULTS}

\section{Glucose tolerance}

The tolerance curves (Fig. I) of the two groups were not significantly different.

\section{Plasma FFA}

Fig. 2 shows the fasting plasma FFA concentrations of $\mathrm{Zn}$-deficient and pair-fed, meal-eating, Zn-supplemented rats. After about a week the concentration of FFA in the plasma of the $\mathrm{Zn}$-deficient rats after an overnight fast was nearly twice as great as in the controls, but after about $30 \mathrm{~d}$ the concentration in the $\mathrm{Zn}$-deficient rats had fallen almost to that in the controls. The concentracions of FFA in the plasma of the deficient rats tended to remain higher than in the controls, but this might be expected, since the deficient rats were continuously fed but the controls were meal-eaters (Florence \& Quarterman, r972).

\section{Plasma ketone bodies and cholesterol}

The fasting plasma concentrations of ketone bodies in the $\mathrm{Zn}$-deficient rats were nearly three times as high as in the meal-eating control rats, $6.0 \pm \mathrm{x} \cdot 0 \mathrm{mg} / 100 \mathrm{ml} \mathrm{com}-$ 


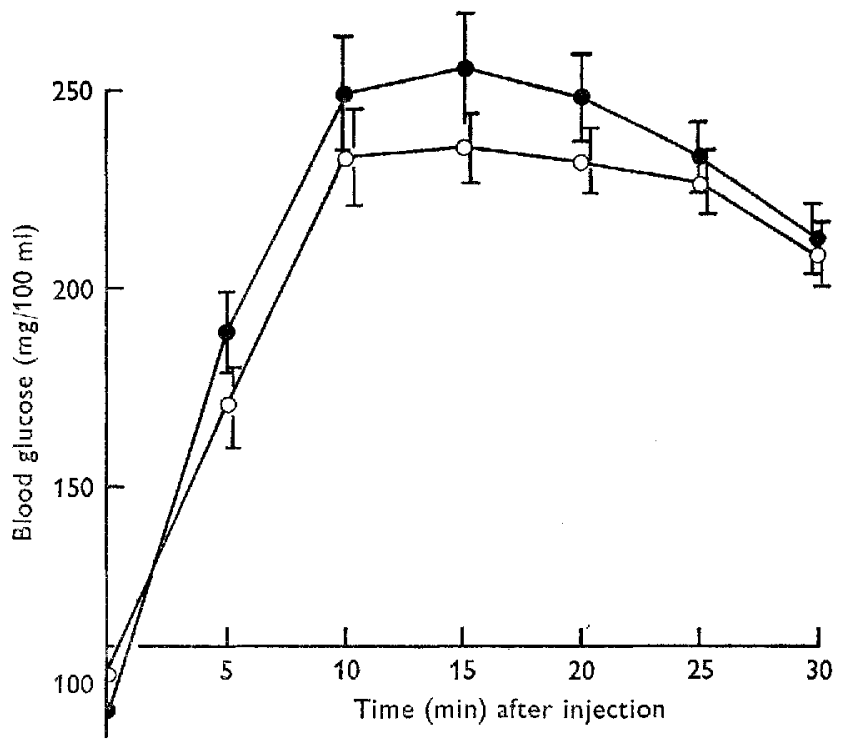

Fig. I. Changes in tail-blood glucose concentration after intraperitoneal administration of glucose ( $175 \mathrm{mg} / \mathrm{roO} \mathrm{g}$ body-weight) to zinc-deficient rats $(\mathrm{O}-\mathrm{O})$ and to continuously fed control rats $(-)$. The vertical bars represent the standard errors of the mean.

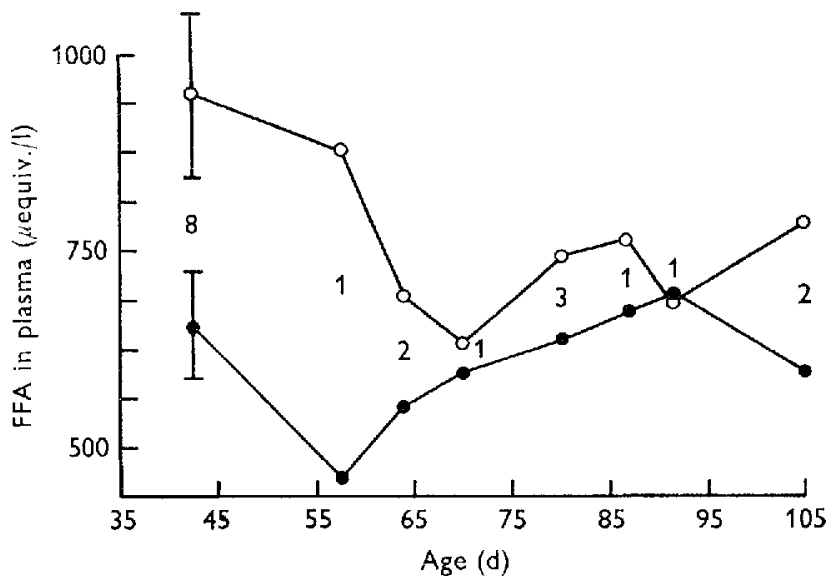

Fig. 2. Changes with time in plasma free-fatty-acid (FFA) concentration of continuously fed zinc-deficient rats $(-O)$ and meal-eating rats given a $\mathrm{Zn}$-supplemented diet $(\mathrm{O}-\mathrm{O})$. The numbers indicate the number of pairs of rats sampled at each time. The difference at $42 \mathrm{~d}$ was highly significant $\left(P<\mathrm{o}^{\circ} \mathrm{OI}\right)$ - for this sampling time, the vertical bars represent the standard errors of the mean.

pared with $2 \cdot 2 \pm 0 \cdot 4 \mathrm{mg} / \mathrm{I00} \mathrm{ml}$. There was no difference in the plasma cholesterol concentrations, $77 \pm 3$ and $73 \pm 4 \mathrm{mg} / \mathrm{I} 00 \mathrm{ml}$, between the deficient and control groups. The rats in which plasma ketone bodies were determined had received the experimental diets for $29 \mathrm{~d}$; those used for cholesterol determinations received the diet for I6-IOI d. 


\section{Plasma insulin concentrations}

The concentrations of insulin in plasma taken ${ }_{5} 5$ min after a dose of glucose in six $\mathrm{Zn}$-deficient rats, six continuously fed rats and three meal-eating rats, all $40-50 \mathrm{~d}$ of age, were not significantly different, being $54 \pm \mathrm{I} 2,63 \pm 8$ and $70 \pm 8 \mu \mathrm{units} / \mathrm{ml}$ respectively.

\section{DISCUSSION}

It has previously been reported that there was a poorer glucose tolerance than normal in $\mathrm{Zn}$-deficient rats than controls (Hove et al. 1937; Quarterman et al. I966; Hendricks, Mahoney \& McClusky, I971). The observed effect has, however, been attributed to a difference in feeding pattern between $\mathrm{Zn}$-deficient rats eating slowly and continuously and their meal-fed pair-mates which eat their food over a relatively short period (Macapinlac, Pearson \& Darby, r966). We now believe from the evidence presented in this and the previous paper (Florence \& Quarterman, 1972) that the amount of food eaten during the day preceding the glucose tolerance test is the decisive factor. The imposition of different fecding patterns on an animal leads necessarily to the consumption of different amounts of food before an overnight starvation. Thus, animals feeding continuously, either because they are given food ad lib. (Florence \& Quarterman, 1972) or because they are fed by a continuous feeder (Quarterman et al. I970), receive their food from the time of the morning feed until food is withdrawn before starvation, usually for about $8 \mathrm{~h}$, and thereby consume about a third of their day's food. Zn-deficient rats are usually fed $a d$ lib. and are in this category of continuous feeders. Meal-eating rats, such as the pair-fed controls in our experiments and those of Macapinlac et al. (I966), soon adapt themselves to eating the whole of their day's food in much less than $8 \mathrm{~h}$.

A previous report (Quarterman et al. 1966) described a small decrease in plasma insulin of $\mathrm{Zn}$-deficient rats compared with $\mathrm{Zn}$-supplemented rats following an intraperitoneal dose of glucose. The rats were then about $70 \mathrm{~d}$ of age and the concentrations were much lower than those observed in the present work where the rats were about $45^{-50 ~ d ~ o f ~ a g e . ~ A ~ d e c r e a s e ~ i n ~ p l a s m a ~ i n s u l i n ~ w i t h ~ a g e ~ i n ~ t h i s ~ a g e-r a n g e ~ h a s ~ b e e n ~}$ described by Florence \& Quarterman (1972). In both experiments the plasma insulin concentration was lower in the Zn-deficient rats, though in the present work the difference was not statistically significant. This decrease in the $\mathrm{Zn}$-deficient rats is insufficient to affect the glucose tolerance, which changes with age in the same way as in $\mathrm{Zn}$-treated animals (Florence \& Quarterman, 1972).

Soon after young rats are given a $\mathrm{Zn}$-deficient diet there is a large increase in the fasting plasma FFA concentration which cannot be accounted for by any aspect of dietary history except $Z n$-deficiency, since the plasma FFA concentrations of continuously fed rats of the same age on the $\mathrm{Zn}$-supplemented diet are only $760 \pm 30 \mu$ equiv. $/ 1$ (Florence \& Quarterman, 1972). After 2 or 3 weeks the value has fallen to nearly that of the meal-eating controls. The tendency for the concentration in the deficient rats to be higher than in these controls after the 3 rd week could be due to the different feeding systems of the two groups. The same considerations probably apply to the plasma 
ketone body concentrations. Very small additions of $\mathrm{Zn}$ have been shown to affect glucose uptake by rat adipose tissue in vitro (Quarterman, 1969 ) and the glucose uptake of adipose tissue from $\mathrm{Zn}$-deficient rats is much less than that from rats given a $\mathrm{Zn}$ supplement. The changes in FFA and ketone body concentrations are evidence that some disturbance in adipose tissue metabolism is occurring in vivo. This disturbance may be such as to result in degradation of the triglyceride reserves, causing in turn high FFA concentrations in the blood.

We are indebted to Dr P. D. Bewsher of the Department of Pharmacology and Therapeutics, Medical School, University of Aberdeen, for the insulin assays.

\section{REFERENCES}

Florence, E. \& Quarterman, J. (1972). Br. F. Nutr. 28, 63.

Hendricks, D. G., Mahoney, A. W. \& McClusky, K. W. (1971). Fedn Proc. Fedn Am. Socs exp. Biol. 30, 406 .

Hove, E., Elvehjem, C. A. \& Hart, E. B. (1937). Am. F. Physiol. r19, 768.

Logothetopoulos, J., Kanek, M., Wrenshall, A. \& Best, C. H. (1964). The Structure and Metabolism of the Pancreatic Islets p. 333. New York: Pergamon Press.

Macapinlac, M. P., Pearson, W. N. \& Darby, W. J. (1966). In Zine Metabolism p. I53 [A. S. Prasad, editor]. Springfield, Ill.: Charles C. Thomas.

Petkov, von P. \& Galabova, R. (1969). Acta histochem. 32, 93.

Quarterman, J. (1969). Biochim. biophys. Acta r77, 644.

Quarterman, J., Mills, C. F. \& Humphries, W. R. (r966). Biochem. biophys. Res. Commun, 25, 354.

Quarterman, J., Williams, R. B. \& Humphries, W. R. (1970). Br. F. Nutr. 24, 1049.

Tanayama, S. \& Ui, M. (I963). Chem. pharm. Bull., Tokyo I1, 835 .

Williams, R. B. \& Mills, C. F. (1970). Br. F. Nutr. 24, 989. 